Jurnal PAI Raden Fatah

Vol. 2, No. 2, (April 2020): 132-147

\title{
IMPLEMENTASI MANAJEMEN BERBASIS MADRASAH (MBM) DALAM MENINGKATKAN KUALITAS PEMBELAJARAN DI MADRASAH ALIYAH NEGERI 2 LUBUKLINGGAU
}

Kholai

STAI Bumi Silampari Lubuklinggau

Sumatera Selatan

kholai@gmail.com

Fitriyani

STAI Bumi Silampari Lubuklinggau Sumatera Selatan fitriyani@staibsllg.ac.id

Muhammad Qomarullah

STAI Bumi Silampari Lubuklinggau Sumatera Selatan

muhammadqomarullah@gmail.com

\begin{abstract}
Education is a conscious and planned effort in
\end{abstract} realizing an atmosphere of learning and learning process so that students actively develop their potential to have religious spiritual strength, self-control, personality, intelligence, noble character, and the skills needed by themselves, the people of the nation and the State. Based on these problems, the formulation of the research problem is: (1) How is the quality of learning in MAN 2 Lubuklinggau (2) How is the implementation of Madrasah Based Management in improving the quality of learning in MAN 2 Lubuklinggau (3) What are the supporting and inhibiting factors that influence the Implementation of Madrasah Based Management in improving the quality of learning at MAN 2 Lubuklinggau

This research is a qualitative descriptive research. With the Head of Madrasa as the research subject. In collecting data, the authors use the method of observation, interviews and documentation. Data is collected from the information specified, the results relevant to the problem under study are analyzed quantitatively through the process of data collection, data reduction, data presentation and drawing conclusions.

The results of this study indicate that the quality of the learning process in Madrasah Aliyah Negeri 2 Lubuklinggau can be said to be good. This is evident from the teachers who teach in accordance with their respective educational qualifications. With the Implementation of Madrasah-Based Management in improving the quality of learning at MAN 2 Lubuklinggau, it reveals the Management of Madrasas, the performance of Madrasah Heads / teachers, and the role of Community Participation. The implementation of the Madrasah-Based Management Program will be carried out well with the collaboration between Curriculum Management and Teaching Programs, Management of Education Personnel, Student Management, Financial Management and Financing, Management of Educational Facilities and Infrastructure, Management of School and Community Relations, and Management of Special Services.

Keywords: Madrasah Based Management, Quality of Learning 


\section{PENDAHULUAN}

Madrasah merupakan lembaga pendidikan yang lahir dan untuk masyarakat, sebab keberadaan madrasah sebagaimana yang kita saksikan saat ini merupakan lembaga yang lahir dari masyarakat dalam rangka untuk mencerdaskan kehidupan anak bangsa. Malik Fadjar mengemukakan bahwa "Madrasah adalah madrasah", artinya madrasah adalah lembaga yang tidak dapat digantikan oleh lembaga lain, karena madrasah mempunyai visi, misi, dan karakteristik yang sangat khas di dalam masyarakat Indonesia baik dilihat dari segi kebudayaan, pendidikan, politik, bahwa ekonomi. ${ }^{1}$

Dalam upaya untuk meningkatkan sumber daya manusia, dunia pendidikan mempunyai peranan yang sangat penting terutama mempersiapkan generasi baru yang mampu menjadi penerus dan pelaksana pembangun di segala bidang. Adapun makna dari pendidikan juga termaktub dalam Al-Qur'an di dalam Surah Al-Baqarah ayat 31:

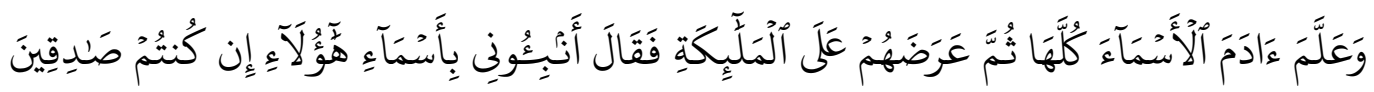

\section{Artinya:}

"Dan Dia mengajarkan kepada Adam nama-nama (benda-benda) seluruhnya, kemudian mengemukakannya kepada para Malaikat lalu berfirman: Sebutkanlah kepada-Ku nama benda-benda itu jika kamu mamang benar orang-orang yang benar". ${ }^{2}$

Salah satu permasalahan pendidikan yang dihadapi bangsa Indonesia adalah rendah mutu pendidikan pada setiap jenjang dan satuan pendidikan, khususnya pendidikan dasar dan menengah. Sebenarnya usaha yang dilakukan dalam rangka meningkatkan mutu pendidikan telah banyak dilakukan baik dari aspek kualifikasi guru, sarana, kurikulum maupun pengadaan buku dan alat pelajaran.

Masalah mutu pendidikan di Indonesia saat ini merupakan isu sentral bidang pendidikan di samping masalah pemerataan akses pendidikan. Peningkatan mutu sumber daya manusia Indonesia sebenarnya merupakan amanat dari Undang-Undang Tentang Sistem Pendidikan Nasional No. 20 Tahun 2003 yang di

\footnotetext{
${ }^{1}$ Muhammad Rais, Manajemen Marketing Pendidikan Madrasah (Yogyakarta: Pustaka Ilmu, 2013), hlm. 1.

${ }^{2}$ Dapartemen Agama RI, Al-Hikmah, Al-Qur'an Terjemah (Bandung: Diponegoro, 2006), hlm. 6 .
} 
antara lain menjelaskan bahwa pendidikan adalah usaha sadar dan terencana untuk mewujudkan suasana belajar dan proses pembelajaran agar peserta didik secara aktif mengembangkan potensi dirinya untuk memiliki kekuatan spiritual keagamaan, pengendalian diri, kepribadian, kecerdasan, akhlak mulia, serta ketrampilan yang diperlukan dirinya, masyarakat bangsa dan negara. ${ }^{3}$

Manajemen Berbasis Madrasah (MBM) sebagai model manajemen yang memberikan otonomi lebih besar pada masrasah dan mendorong pengambilan keputusan partisipasi yang melibatkan secara langsung semua warga madrasah untuk meningkatkan mutu madarasah berdasarkan kebijakan pendidikan nasional. Dalam bukunya yang berjudul "Manajemen Berbasis Sekolah (Konsep, Strategi, dan Implementasi)", Mulyasa menyebutkan bahwa Manajemen Berbasis Sekolah merupakan suatu konsep yang menawarkan otonomi pada sekolah untuk menentukan kebijakan sekolah dalam rangka meningkatkan mutu, efisiensi dan pemerataan pendidikan agar dapat mengakomodasi keinginan masyarakat setempat serta menjalin kerja sama yang erat antara pihak sekolah, masyarakat, dan pemerintah. ${ }^{4}$

Dengan adanya hak otonomi lembaga/madrasah yang diberikan oleh pemerintah pusat, maka Madrasah Aliyah Negeri 2 Lubuklinggau bisa leluasa melaksanakan dan mengembangkan pendidikannya dengan cara atau metode yang ada pada madrasah tersebut dengan tidak keluar dari tujuan pendidikan, dimana sekolah tersebut berusaha meningkatkan efisiensi, kualitas, dan pemerataan pendidikan serta menciptakan pembelajaran yang efektif, menyenangkan, mengasyikkan, dan produktif, sehingga nantinya mampu menciptakan lulusan yang sesuai dengan tuntutan masyarakat luas karena dalam MBM ini sekolah, masyarakat, dan pemerintah dituntut untuk mengadakan kerja sama dalam menentukan arah pendidikan dan tujuan pendidikan.

Berkaitan dengan penyiapan sumber daya manusia untuk menghadapi tantangan global pada abad teknologi dan informasi, komite untuk meningkatkan kualitas pendidikan hendaknya tidak berubah pemerintah tetap konsisten untuk

${ }^{3}$ Departemen Agama RI, Memahami Paradigm Baru Pendidikan Nasional dalam UndangUndang SISDIKNAS (Jakarta: Dep. RI, Dirjenkelembagaan Agama Islam, 2003), hlm. 4.

${ }^{4}$ E. Mulyasa, Manajemen Berbasis Sekolah (Konsep, Strategi, dan Implementasi) (Bandung: PT. Remaja Rosdakarya, 2005), hlm. 11. 
meningkatkan kualitas maupun kualitas pendidikan. Agar mampu mencapai hasil yang telah optimal, efektif dan efesien dalam menangani berbagai masalah pendidikan, pemerintah daerah tidak mungkin dapat bekerja secara sendiri, karena masih ada pihak-pihak lain yang berkepentingan terhadap bidang pendidikan terersebut, seperti orang tua (masyarakat), sekolah (lembaga pendidikan), dan institusi sosial lain seperti dunia usaha atau dunia industri.

Manajemen Berbasis Madrasah (MBM) menekankan keterlibatan maksimal berbagai pihak, seperti kepala madrasah, dewan guru, siswa, orang tua, komite madrasah, maupun pemerintah pendidikan. Semua ini hendaknya berjalan secara efektif guna mencapai tujuan pendidikan. Dalam melaksanakan tanggung jawab tersebut, komponen Madrasah mempunyai peranan dalam menentukan tujuan yang ditetapkan, untuk itu kualitas profesi tenaga kependidikan perlu ditingkatkan. Selain itu, Manajemen Berbasis Madrasah (MBM) menawarkan Kepada Sekolah untuk menyediakan pendidikan yang lebih memadai bagi peserta didik. Adanya otonomi daerah dalam pengeloaan pendidikan merupakan potensi bagi sekolah untuk meningkatkana kinerja para personil, menawarkan partisipasi langsung baik pihak-pihak terkait, dan meningkatkan pemahaman masyarakat terhadap penyelenggaraan pendidikan di sekolah. ${ }^{5}$ Dengan MBM, unsur pokok sekolah memegang kontrol yang lebih besar dalam setiap kejadian disekolah. Unsur pokok sekolah ini kemudian menjadi lembaga non-struktural yang disebut Komite Sekolah yang anggotanya adalah Kepala sekolah, Guru Administrator, orang tua/wali murid, anggota masyarakat dan murid.

Berdasarkan hasil observasi di Madrasah Aliyah Negeri 2 Lubuklinggau mengenai Manajemen Berbasis Madrasah, maka Madrasah Aliyah Negeri 2 Lubuklinggau hendaknya mampu membuat organisasi, pembelajaran dan meningkatkan kualitas pendidikan yang mampu melakukan proses belajar mengajar yang efektif dan efesien sehingga menghasilkan pendidikan yang berkualitas, maka perlu diadakan tindakan rencanaan pembelajaran yang baik terutama manajemennya. ${ }^{6}$ 196.

${ }^{5}$ Suryo Subroto, Manajemen Pendidikan di Sekolah (Jakarta: Rineka Cipta, 2004), hlm.

${ }^{6}$ Hasil Observasi di Madrasah Aliyah Negeri 2 Lubuklinggau pada tanggal 26 April 2018 Pukul 08:15 WIB. 


\section{METODE PENELITIAN}

Jenis penelitian ini adalah penelitian lapangan (fied research) dengan pendekatan kualitatif. Dalam hal ini penulis menekankan pada penelitian lapangan fied research yang bersifat deskritif analitik yang menggunakan pendekatan kualitatif yaitu uraian naratif suatu proses tingakah laku subjek yang sesuai dengan masalah yang diteliti. ${ }^{7}$ Jadi penelitian ini termasuk jenis penelitian deskritif kualitatif, yaitu penelitian yang berusaha menggambarkan, menguraikan dan menjelaskan mengenai Manajemen Berbasis Madrasah (MBM) di Madrasah aliyah Negeri 2 Lubuklinggau.

Dalam melakukan analisa data penulis mengacu kepada pendapat yang diungkapkan oleh Patton yaitu proses mengatur urutan data, mengorganisasikan ke dalam suatu pola, kategori dan satuan uraian dasar. Ia membedakan dengan penafsiran, yaitu memberikan arti yang signifikat terhadap hasil analisis, menjelaskan pola uraian, dan mencari hubungan diantara dimensi-dimensi aturan. ${ }^{8}$ Aktifitas dalam analisis data yaitu data reduction, data display, dan conclusion drwing/verification. Dan analisa data ini dilakukan setelah data-data terkumpul melalui wawancara, observasi dan dokumentasi.

\section{HASIL DAN PEMBAHASAN}

\section{A. Kualitas Pembelajaran dan Implementasi Manajemen Berbasis Madrasah}

Berdasarkan indikator kualitas pembelajaran tersebut dapat dikaitkan dengan Implementasi Manajemen Berbasis Madrasah yang mana dalam hal ini berkaitan dengan peran dan fungsi manajemen dalam meningkatkan kualitas pembelajaran yang ada di Madrasah Aliyah Negeri 2 Lubuklinggau sebagai berikut:

1. Manajemen Kurikulum dan Program Pengajaran

Kurikulum adalah seperangkat rencana dan pengaturan mengenai tujuan, kompetensi dasar, materi standar, dan hasil belajar, serta cara yang digunakan sebagai pedoman penyelenggaraan kegiatan

${ }^{7}$ Amirudin hadi dan Haryono, Metodologi Penelitian Pendidikan (Jakarta: Pustaka Setia, 1998), hlm. 17.

${ }^{8}$ Sugiyono, Memahami Penelitian Kualitatif (Bandung: Alfabeta, 2008), hlm. 92-93. 
pembelajaran untuk mencapai kompetensi dasar tujuan pendidikan. Dalam konteks ini, Madrasah Aliyah Negeri 2 Lubuklinggau juga melakukan evaluasi. Menurut Waka Kurikulum Arina Suyetty, evaluasi kurikulum dilaksanakan pada 2 periode. Periode pertama yaitu pada akhir semester. Evaluasi pada periode ini adalah evaluasi berupa rapat koordinasi yang digunakan untuk mengetahui hambatan-hambatan yang terjadi dalam kegiatan pelaksanan kurikulum.

Untuk mengetahui manajemen kurikulum dan program pengajaran dalam Implementasi Manajemen Berbasis Madrasah dalam meningkatkan kualitas pembelajaran di MAN 2 Lubuklinggau peneliti mewawancarai Kepala Madrasah Saipul Basin, S.Pd.M.M mengatakan bahwa:

"Dalam pelaksanaannya kami di sini sudah menetapkan beberapa ketentuan yang harus dilaksanakan oleh unsur-unsur yang ada di sekolah ini, misalnya: menetapkan jadwal pelajaran, menetapkan penyusunan prota, promes, RPP, silabus, dan lain sebagainya. Sehingga dengan mengacu pada ketetapan ini, diharapkan nantinya proses pembelajaran bisa berjalan secara maksimal yang pada akhirnya akan menciptakan output yang maksimal juga. Selain itu, kami memodifikasi kurikulum yakni dengan cara melakukan perbaikan dan pembenahan kurikulum yang sudah tidak layak lagi.",9

Selanjutnya mengenai manajemen kurikulum dan program pengajaran dalam Implementasi Manajemen Berbasis Madrasah dalam meningkatkan kualitas pembelajaran di MAN 2 Lubuklinggau peneliti mewawancarai Waka Kurikulum ibu Dra. $\mathrm{Hj}$. Arina Suyyety menyebutkan bahwa:

"Evaluasi ini berupa rapat koordinasi yang digunakan untuk mengetahui keluhan-keluhan yang dihadapi guru dalam melaksanakan tugasnya. Dari keluhan-keluhan itu di cari jalan solusi dan alternatif yang terbaik agar pada semester berikutnya masalah serupa tidak timbul lagi. Sedangkan evaluasi periode kedua adalah evaluasi secara total (menyeluruh)." 10

\footnotetext{
${ }^{9}$ Wawancara dengan Saipul Basin selaku Kepala Madrasah di MAN 2 Lubuklinggau 29 November 2018 Pukul 10:45 WIB.

${ }^{10}$ Wawancara dengan Arina Suyetty selaku Waka Kurikulum di MAN 2 Lubuklinggau 28 November 2018 Pukul 13:36 WIB.
} 
Dari hasil wawancara di atas, bagian kurikulum MAN 2 Lubuklinggau sudah menetapkan program kerja dalam bidang kurikulum meliputi program tahunan (prota), program semester, rencana pembelajaran dan pembuatan silabus. Ini merupakan pembagian tugas mengajar guru. Sehingga nantinya para guru sebelum melaksanakan pembelajaran diwajibkan untuk menyusun program tahunan (prota), program semester, rencana pembelajaran dan silabus. Dan dengan adanya kewajiban tersebut proses belajar mengajar akan berjalan dengan lancar yang pada akhirnya akan mengantarkan siswa pada tujuan yang telah ditetapkan.

2. Manajemen Tenaga Kependidikan

Madrasah Aliyah Negeri 2 Lubuklinggau dikelola dan dibina oleh tenaga profesional pimpinan sekolah, guru, dan karyawan merupakan sumber daya manusia pilihan yang memiliki dedikasi tinggi, akhlak mulia dan memiliki kualifikasi sesuai dengan bidangnya. Untuk mengetahui manajemen Tenaga Kependidikan dalam Implementasi Manajemen Berbasis Madrasah dalam meningkatkan kualitas pembelajaran di MAN 2 Lubuklinggau peneliti mewawancarai Kepala Madrasah Saipul Basin, S.Pd.M.M mengatakan bahwa:

"Dalam bidang ini kami menetapkan beberapa program yang sekiranya dapat menunjang terhadap kualitas belajar mengajar siswa, artinya kami di sini mengusahakan beberapa hal untuk meningkatkan proses belajar mengajar yang pada akhirnya akan meningkatkan prestasi siswa itu sendiri. Program-program tersebut misalnya kami mengadakan musyawarah atau rapat mengenai halhal yang telah dilakukan dalam satu semester, intinya kami melakukan evaluasi setiap akhir semester. Selain itu, kami juga mengutus mereka untuk mengikuti seminar, whorkshop, diklat, dan lain-lain yang berkaitan dengan peningkatan profesionalitas guru serta jika dimungkinkan kami menugaskan mereka untuk studi lanjutan."11

Selanjutnya mengenai manajemen Tenaga Kependidikan dalam Implementasi Manajemen Berbasis Madrasah dalam meningkatkan

\footnotetext{
${ }^{11}$ Wawancara dengan Saipul Basin selaku Kepala Madrasah di MAN 2 Lubuklinggau 29 November 2018 Pukul 10:45 WIB.
} 
kualitas pembelajaran di MAN 2 Lubuklinggau peneliti mewawancarai ibu Dra. Kartini yang mengatakan bahwa:

"Dalam manajemen ketenaga pendidikan, pembagian tugas guru sesuai dengan skil yang ada contohnya ibu yang ngajar dibidang agama ngajar dibidang agama, pembagian tugas guru sesuai porsinya. Guru juga harus biasa mengatur waktu yang sesuai dengan RPP, diawali pendahuluan, Aprepsepsi dan diakhiri dengan evaluasi dengga guru mengetahui hasil dan kemampuan anak didik." 12

Dari hasil wawancara di atas, dapat disimpulkan bahwa dalam manajemen tenaga pendidikan, setiap satu semester di sana mengadakan rapat untuk mengevaluasi tentang hal-hal yang telah dilakukan selama satu semester. Dengan demikian maka proses belajar mengajar yang diterapkan di MAN 2 Lubuklinggau akan betul-betul mempunyai mutu yang cukup tinggi atau dengan kata lain dengan adanya usaha-usaha tersebut nantinya akan berdampak pada peningkatan proses belajar mengajar. Oleh karena itu, tenaga teknis atau guru di MAN 2 Lubuklinggau diharapkan benar-benar profesional dan harus meguasai bidang mata pelajaran yang diajarkannya karena guru sangat berpengaruh terhadap jalannya proses belajar mengajar siswa dan prestasi belajarnya. Guru sebagai fasilitator yang mengarahkan belajar siswa karena keberhasilan seorang siswa itu juga sangat berpengaruh terhadap pengajaran guru.

3. Manajemen Kesiswaan

Siswa merupakan salah satu komponen yang mendukung terhadap terjadinya proses belajar mengajar dan siswa juga mempunyai potensi sendiri-sendiri yang dinamakan perlengkapan dasar maupun perlengkapan ajar. Setiap anak, potensi tersebut berbeda baik dalam segi kualitasnya atau dalam segi bidang-bidang potensinya. Anak sebagai pihak yang membutuhkan pendidikan, batas kemampuan pendidikan yang diberikan kepadanya ditentukan oleh kualitas potensi yang ada.

\footnotetext{
${ }^{12}$ Wawancara dengan Kartini selaku guru mata pelajaran AL-Qur'an Hadist di MAN 2 Lubuklinggau 27 November 2018 Pukul 11:36 WIB.
} 
Untuk mengetahui Implementasi Manajemen Berbasis Madrasah dalam meningkatkan kualitas pembelajaran di MAN 2 Lubuklinggau peneliti mewawancarai Kepala Madrasah Saipul Basin, S.Pd.M.M mengatakan bahwa:

"Ada beberapa hal yang dilakukan dalam bidang kesiswaan, seperti: kami di sini menambah jam pelajarannya bagi mereka yang lebih membutuhkan yaitu siswa kelas 12 yang akan menghadapi UASBN sebagai penentu kelulusan mereka dan selain itu kami menopangnya atau memberikan beberapa materi atau pelajaranpelajaran tambahan dalam bentuk kegiatan ektra kurikuler, seperti: Unit Kegiata Siswa (UKS), olah raga dan seni, rohis, Mapala, PMR dan pramuka."13

Selanjutnya, peneliti melakukan wawancara dengan waka kesiswaan:

"Output atau hasil akhir dari profil lulusan Madrasah Aliyah Negeri 2 Lubuklinggau adalah terbentuknya peserta didik yang sesuai standar kompetensi lulusan, yaitu akidah yang lurus kemampuan beribadah yang benar, memiliki wawasan yang luas, usaha untuk rapi dalam setiap urusan, mempunyai akhlak yang mulia, mengatur waktu yang baik, mempunyai kemampuan berusaha, mempunyai fisik yang kuat, kemampuan menahan hawa nafsu, dan berlatih untuk bermanfaat bagi orang lain." 14

Dari paparan di atas tentang Manajemen Kesiswaan dapat disimpulkan bahwa Manajemen kesiswaan bertujuan untuk mengatur berbagai kegiatan kesiswaan agar kegiatan pembelajaran di sekolah berjalan lancar, tertib dan teratur, serta mencapai tujuan pendidikan sekolah.

4. Manajemen Sarana dan Prasarana Pendidikan

Sarana dan prasarana yang ada di Madrasah Aliyah Negeri 2 lubuklinggau sudah cukup memenuhi kreteria dengan adanya manajemen sarana dan prasarana yang ada kegiatan pembelajran menjadi efektif. Untuk mengetahui Manajemen Kesiswaan dalam Implementasi Manajemen Berbasis Madrasah dalam meningkatkan kualitas

\footnotetext{
${ }^{13}$ Wawancara dengan Saipul Basin selaku Kepala Madrasah di MAN 2 Lubuklinggau 29 November 2018 Pukul 10:45 WIB.

${ }^{14}$ Wawancara dengan Joharudin selaku Waka Kesiswaan di MAN 2 Lubuklinggau 30 November 2018 Pukul 10:49 WIB.
} 
pembelajaran di MAN 2 Lubuklinggau peneliti mewawancarai Waka Kurikulum Dra. Hj. Arina suyetty mengatakan bahwa:

"Manajemen sarana dan prasarana di MAN 2 ini sadah cukup lengkap seperti, tenaga kependidikan, dan sebagainya cukup mendukung. Dengan adanya alat atau media yang ada di sana, seperti: tempat belajar yang kondusif, perpustakaan, musholla, UKS, Ruang OSIS, Ruang Komputer, Ruang Lab, Ruang BK, Lapangan Olah Raga, Ruang Keterampilan, dan lain sebagainya yang cukup memadahi sehingga dengan adanya semua itu akan menunjang bagi lancarnya belajar siswa" 15

Dari paparan diatas dapat disimpulkan bahwa dalam bidang ini, MAN 2 Lubuklinggau berusaha semaksimal mungkin guna menciptakan sekolah yang bersih, rapi, dan indah sehingga menciptakan situasi dan kondisi yang menyenangkan bagi warga sekolah, sehingga dapat memperlancar jalannya proses pembelajaran yang pada akhirnya proses pembelajaran tersebut dapat ditingkatkan.

5. Manajemen Hubungan Sekolah dan Masyarakat

Perencanaan manajemen hubungan madrasah dengan masyarakat tidak bias berdiri sendiri. Keberadaan Madrasah Aliyah Negeri 2 Lubuklinggau, memiliki nilai plus yakni mampu melahirkan calon pemimpin masa depan yang menguasai ilmu pengetahuan dan teknologi, mempunyai daya juang tinggi, kretif, inovatif, proaktif, dan mempunyai landasan iman dan takwa yang kuat. Partisipasi yang tinggi dari orang tua murid dalam pendidikan di madrasah merupakan salah satu ciri dari penggelolaan madrasah yang baik, artinya sejauh mana masyarakat dapat diberdayakan dalam proses pendidikan terhadap manajemen berbasis madrasah yang bersangkutan.

Untuk mengetahui manajemen Hubungan dalam Masyarakat dalam Implementasi Manajemen Berbasis Madrasah dalam meningkatkan kualitas pembelajaran di MAN 2 Lubuklinggau peneliti mewawancarai Kepala Madrasah Saipul Basin, S.Pd.M.M mengatakan bahwa:

"Hubungan sekolah kita dengan masyarakat sekitar khususnya cukup terjalin dengan baik, Dengan partisipasi masyarakat serta

\footnotetext{
${ }^{15}$ Wawancara dengan Arina Suyetty selaku Waka Kurikulum di MAN 2 Lubuklinggau 28 November 2018 Pukul 13:36 WIB.
} 
dukungan dan sumbangsih pemikiran maupun dana akan berpengaruh terhadap kemajuan sekolah. Dengan kata lain, sekolah merupakan lembaga sosial yang berfungsi untuk melayani anggotaanggota masyarakat dalam bidang pendidikan. Masyarakat merupakan salah satu dari pusat pendidikan yang juga mempunyai tanggung jawab terhadap masalah-masalah pendidikan."

6. Manajemen Layanan Khusus

Untuk mengetahui Manajemen Layanan khusus dalam Implementasi Manajemen Berbasis Madrasah dalam meningkatkan kualitas pembelajaran di MAN 2 Lubuklinggau peneliti mewawancarai Kepala Madrasah Saipul Basin, S.Pd.M.M mengatakan bahwa:

"Kegiatan belajar mengajar harus menempatkan peserta didik sebagai subyek belajar artinya kegiatan belajar mengajar harus memperhatikan bakat, minat kemampuan, cara, strategi dan motivasi belajar serta latar belakang social pesertaa didik. Dalam mewujudkan siswa yang berpikir kreatif dan kritis, Madrasah Aliyah Negeri 2 Lubuklinggau mempunyai beberapa program untuk menigkatkan prestasi siswa-siswanya dalam manajemen layanan khusus antara lain: Responsi (pengguasaan konsep dan penggayan dalam jam regular.). pemanfaatan teknologi dalam pembelajaran baik berupa sumber belajar maupun sarana belajar." 16

Berdasarkan uraian di atas, dalam implementasi Program Manajemen Berbasis Madrasah ini mengungkap tentang Manajemen Madrasah, kinerja Kepala Madrasah/ guru, dan peran Serta Masyarakat. Dalam implementasi Program Manajemen Berbasis Madrasah akan terlaksana dengan baik adanya kerja sama anatara Manajemen Kurikulum dan Program Pengajaran, Manajemen Tenaga Kependidikan, Manajemen Kesiswaan, Manajemen Keuangan dan Pembiayaan, Manajemen Sarana dan Prasarana Pendidikan, Manajemen Hubungan Sekolah dan Masyarakat, dan Manajemen Layanan Khusus.

7. Kualitas Pembelajaran di MAN 2 Lubuklinggau

Untuk mengetahui tingkat kualitas pembelajaran di MAN 2 Lubuklinggau, penulis melakukan wawancara dengan Kepala Madrasah dan Guru lainya. Pertanyaan pertama yaitu "Apakah semua guru disini 
mengajar sesuai dengan bidang keahlian mereka masing-masing. Bapak

Saipul Basin selaku Kepala Madrasah menjawab bahwa:

"Ya, dapat dilihat dari tugas yang saya bagikan bahwa guru mengajar dengan kualifikasi pendidikan mereka masing-masing, karena hal ini sangat mempengaruhi keberhasilan dari kegiatan pembelajaran tersebut. Mereka yang mengajar mampu mengusai materi pelajaran yang akan mereka ajarkan. Guru yang mengajar sesuai dengan keahliannya dapat dikatakan sebagai guru yang profesional". ${ }^{17}$

Selanjutnya penulis mewawancarai dengan Guru dengan pertanyaan yang sama di atas, beliau mengatakan bahwa:

"Dalam manajemen ketenaga pendidikan pembagian tugas guru sesuai dengan skil yang mereka miliki, misalnya Ibu Siti Hadida yang merupakan lulusan sarjana Agama, beliau mengajar mata pelajaran Aqida Akhlak. Jika guru mengajar bukan skilnya maka pencapaian pembelajaran tidak efektif dan efesien. Guru harus mempunyai kualifikasi akademik dan latar belakang pendidikan sesuai dengan tugas mengajarnnya." 18

Dari ungkapan di atas tentang guru yang mengajar sesuai dengan bidangnya dapat disimpulkan bahwa guru yang mengajar di MAN 2 Lubuklinggau harus sesuai dengan bidang dan keahlian mereka. Guru harus mempunyai kualifikasi akademik dan latar belakang sesuai dengan tugas.

Berdasarkan wawancara yang peneliti lakukan dengan pertanyaan dari hasil pembelajaran "Adakah peningkatan prestasi dalam pembelajaran di MAN 2 Lubuklinggau? Peneliti mewawancarai Kepala Madrasah Saipul Basin, S.Pd.M.M mengatakan bahwa:

"Dari hasil pembelajaran dapat meningkatan prestasi siswa seperti berkembangan kegiatan ekstrakulikuler di sekolah untuk merangkul anak-anak menunjukan bakat yang mereka miliki, jika anak bakat di seni ada ekstrakulikuler hadroh sekolah menyediakan ruang untuk anak mengembangkan bakat anak. mereka ikut serta dalam

\footnotetext{
${ }^{17}$ Wawancara dengan Saipul Basin selaku Kepala Madrasah di MAN 2 Lubuklinggau 29 November 2018 Pukul 10:45 WIB.

${ }^{18}$ Wawancara dengan Kartini selaku guru mata pelajaran AL-Qur'an Hadist di MAN 2 Lubuklinggau 27 November 2018 Pukul 11:36 WIB.
} 
berbagai lomba yang dilaksanakan d MAN 1 dan Alhamdulillah tim hadro dapat juara." 19

Selanjutnya peneliti mewawancarai Ibu Dra. Kartini dengan pertanyaan yang sama mengatakan bahwa:

"Kualitas pembelajaran di Madrasah sudah cukup baik banyak siswa yang berprestasi, Sekolah juga menuntut anak untu berprestasi di bidang IPTEK dan juga di bidang agama. Kelas IPS juga pernah mengikuti lomba Akutansi dan mendapatkan Juara 2 yang dilaksanakan di STKIP, seperti kelas agama yang lebih menonjol di bidang agama seperti tahfiz penghafal Al-Qur'an walaupun hanya beberapa jus ada yang hafal 5 jus." 20

Dari ungkapan di atas tentang tingkat prestasi siswa dalam proses pembelajaran di Madrasah Aliyah Negeri 2 Lubuklinggau dapat disimpulkan bahwa tingkat proses prestasi siswa sudah cukup baik lihat dari prestasi yang sudah dicapai siswa dalam berbagai perlombaan yang di ikuti.

B. Faktor Pendukung dan Penghambat Implementasi Manajemen Berbasis Madrasah dalam Meningkatkan Kualitas Pembelajaran Di MAN 2 Lubuklinggau

1. Faktor Pendukung

a. Kepemimpinan Kepala Madrasah

Fungsi utama Kepala madrasah sebagai pemimpin pendidik ialah menciptakan situasi pembelajaran sehingga pendidik dapat mengajar dan peserta didik dapat belajar dengan baik. Dalam melaksanakan fungsi tersebut, kepala madrasah memiliki tanggung jawab ganda yaitu melaksanakan administrasi sekolah sehingga terciptanya situasi pembelajaran yang baik, dan melaksanakan supervise sehingga kemampuan pendidik meningkat dalam membimbing pertumbuhan peserta didiknya.

\footnotetext{
${ }^{19}$ Wawancara dengan Saipul Basin selaku Kepala Madrasah di MAN 2 Lubuklinggau 29 November 2018 Pukul 10:45 WIB.

${ }^{20}$ Wawancara dengan Kartini selaku guru mata pelajaran AL-Qur'an Hadist di MAN 2 Lubuklinggau 27 November 2018 Pukul 11:36 WIB.
} 
b. Peran Tenaga Pendidik dan Kependidikan

Tenaga pendidik dan kependidikan dalam proses pembelajaran memegang peran strategis terutama dalam upaya membentuk watak bangsa melalui pengembangan kepribadian dan nilai-nilai yang di inginkan. Pada Madrasah Aliyah Negeri 2 Lubuklinggau ini, guru sudah terbiasa mengkondusifkan siswa dan mengajak siswa untuk ikut masuk dalam materi tersebut agar berjalan dengan baik.

c. Peran peserta didik

Komponen peserta didik keberadaanya sangat dibutuhkan, terlebih bahwa pelaksanaan kegiatan pendidikan di madrasah, peserta didik merupakan subjek sekaligus objek dalam proses transformasi ilmu pengetahuan dan keterampilan yang diperlukan.

d. Tersedianya sarana dan prasarana pendidikan

Sarana dan prasarana pendidikan adalah peralatan dan perlengkapan yang secara langsung dipergunakan dan menunjang proses pendidikan, khususnya proses pembelajaran di madrasah seperti, gedung, ruang kelas, meja kursi, serta alat-alat dan media pengajaran. Jika dilihat dari letak geografisnya posisi madrash sangat strategis sehingga mudah dijangkau dari berbagai arah sehingga dapat memenuhi kebutuhan masyarakat akan pendidikan khususnya pendidikan agama.

2. Faktor penghambat

Berdasarkan analisis terhadap aspek-aspek yang mempengaruhi maka yang menjadi hambatan dalam implementasi manajemen madrasah tersebut adalah sebagai berikut:

a. Anak didik

Anak didik merupakan salah satu faktor pendidik yang dapat memepengaruhi keberhasilan proses belajar mengajaran. Dalam setiap anak didik kecerdasan yang mereka miliki tidak sama perbedaan yang ada dapat menjadi hambatan bagi perkembangan aspek-aspek anak didik itu sendiri yang pada akhirnya merupakan hambantan bagi perkembangan pendidikan. 
b. Pendidik

Faktor pendidik juga sangat menentukan dalam pengembangan sekolah dan mempengaruh besar dalam keberhasilan pembelajaran anak didik. Guru tidak hanya menguasai materi akan tetapi harus bisa menggunakan jaringan internet atau komputer karena dalam penggunaan komputer sangat penting.

c. Sarana dan Prasarana

Sarana dan prasarana merupakan faktor yang penting dalam kelangsungan proses pembelajaran, namun dalam proses pembelajaran akan terhambat apabila sarana dan prasarana yang masih kurang minsalnya ruang komputer, dan alat-alat laboratorium .

\section{KESIMPULAN}

Implementasi Manajemen Berbasis Madrasah dalam meningkatkan kualitas pembelajaran di MAN 2 Lubuklinggau ini mengungkap tentang Manajemen Madrasah, kinerja Kepala Madrasah dan guru, serta peranMasyarakat. Dalam implementasi Program Manajemen Berbasis Madrasah akan terlaksana dengan baik adanya kerja sama antara Manajemen Kurikulum dan Program Pengajaran, Manajemen Tenaga Kependidikan, Manajemen Kesiswaan, Manajemen Keuangan dan Pembiayaan, Manajemen Sarana dan Prasarana Pendidikan, Manajemen Hubungan Sekolah dan Masyarakat, dan Manajemen Layanan Khusus.

Faktor yang pendukung pelaksanaan implementasi manajemen berbasis madrasah dalam meningkatkan kualitas proses pembelajaran di Madrasah Aliyah Negeri 2 Lubuklinggau ada lima kompomen di antara: 1) Kepemimpinan kepala madrasah, 2) peran serta tenaga pendidik dan kependidikan, 3) tersedianya sarana dan prasarana yang memadai, 4) tersedianya media pembelajaran dan sumber belajar, 5) lingkungan Madrasah. Berdasarkan analisis terhadap aspek-aspek yang mempengaruhi maka yang menjadi hambatan dalam implementasi manajemen madrasah tersebut adalah sebagai berikut: 1) kecerdasan siswa yang berbeda-beda, 2) pendidik yang tidak terlalu menguasai penggunan internet dan komputer, 3) sarana prasarana yang masih kurang lengkap. 


\section{DAFTAR PUSTAKA}

Departemen Agama RI. Al-Hikmah, Al-Qur'an Terjemah. Bandung: Diponegoro, 2006.

Departemen Agama RI. Memahami Paradigm Baru Pendidikan Nasional dalam Undang-Undang SISDIKNAS. Jakarta: Dep. RI, Dirjenkelembagaan Agama Islam, 2003.

Hadi, Amirudin dan Haryono. Metodologi Penelitian Pendidikan. Jakarta: Pustaka Setia, 1998.

Hasil Observasi di Madrasah Aliyah Negeri 2 Lubuklinggau pada tanggal 26 April 2018 Pukul 08:15 WIB.

Mulyasa, E. Manajemen Berbasis Sekolah (Konsep, Strategi, dan Implementasi). Bandung: PT. Remaja Rosdakarya, 2005.

Rais, Muhammad. Manajemen Marketing Pendidikan Madrasah. Yogyakarta: Pustaka Ilmu, 2013.

Subroto, Suryo. Manajemen Pendidikan di Sekolah. Jakarta: Rineka Cipta, 2004.

Sugiyono. Memahami Penelitian Kualitatif. Bandung: Alfabeta, 2008.

Wawancara dengan Arina Suyetty selaku Waka Kurikulum di MAN 2 Lubuklinggau 28 November 2018 Pukul 13:36 WIB.

Wawancara dengan Joharudin selaku Waka Kesiswaan di MAN 2 Lubuklinggau 30 November 2018 Pukul 10:49 WIB.

Wawancara dengan Kartini selaku guru mata pelajaran AL-Qur'an Hadist di MAN 2 Lubuklinggau 27 November 2018 Pukul 11:36 WIB.

Wawancara dengan Saipul Basin selaku Kepala Madrasah di MAN 2 Lubuklinggau 29 November 2018 Pukul 10:45 WIB. 